ROCZNIK

TEOLOGII

KATOLICKIEJ

Tom X

Rok 2011

\title{
Bernadetta Puchalska-Dąbrowska
}

Uniwersytet $w$ Białymstoku

\section{EGZEMPLA Z ŻYCIA ŚWIĘTYCH \\ W DYREKTORIUM BŁ. BOLESŁAWY LAMENT}

\section{EXAMPLES FROM THE LIVES OF SAINTS IN BL. BOLESŁAWA LAMENT'S SUPPLEMENT TO HER RULE}

The aim of the article is to present and analyse examples (exempla) in Bl. Boleslawa Lament's Supplement to her rule and constitutions of the Congregation of the Missionary Sisters of the Holy Family. The genre under discussion was particularly popular in the Middle Ages, however it is still used in sermons and didactic literature. The examples are taken mainly from the lives of the saints particularly associated with the spirituality of the Congregation and are inserted in the main text to illustrate the virtues to be practised by the sisters.

W bieżącym roku minęła dwudziesta rocznica beatyfikacji Bolesławy Lament (1862-1946), założycielki Zgromadzenia Sióstr Misjonarek Świętej Rodziny. Aktu wyniesienia na ołtarze dokonał Papież Jan Paweł II w czasie swej wizyty w Białymstoku - miejscu śmierci Błogosławionej - dnia 5 czerwca 1991 roku. Rocznicowe obchody skłaniają do głębszej refleksji nad osobą i życiem Bolesławy Lament, dziełami, których była inicjatorką, jak również jej spuścizną pozostawioną na piśmie. Jest ona - zważywszy na liczne obowiązki założycielki i pierwszej przełożonej generalnej Zgromadzenia - niezwykle bogata pod względem ilościowym i treściowym. W opinii bliskich sobie osób, jak np. s. Leokadii Górczyńskiej, bł. Bolesława tworzyła tak wiele, że zasłużyła sobie na miano „Bożego pisarza”.

Fragmenty pism Bolesławy Lament oraz ich bardziej lub mniej szczegółowe omówienia rozproszone są w poświęconych jej publikacjach, spośród których s. 88 .

J. Stabińska OSBap, Szukać i zbawiać. Posłannictwo Bolesławy Lament, Warszawa 1991, 
należy wymienić m.in. monografie autorstwa Joachima Romana Bara², Adriany Teresy Gronkiewicz ${ }^{3}$ i Jadwigi Stabińskiej ${ }^{4}$. Aktualnie dostępne zasoby są, niestety, niekompletne. Zniszczenia dokonane w czasie dwóch wojen światowych, przemieszczanie się ludności, jak również domów zakonnych sprawiły, iż do dzisiejszych czasów zachowało się niewiele źródeł autorstwa założycielki Zgromadzenia ${ }^{5}$. Wśród ocalałych pism znalazły się jednakże istotne dla poznania biografii oraz duchowości Błogosławionej teksty o różnej przynależności gatunkowej, które podzielić można - za Joachimem Romanem Barem - na następujące grupy:

- listy pisane głównie w sprawach dotyczących powstania Zgromadzenia oraz jego późniejszej działalności, okólniki rozsyłane do poszczególnych domów zakonnych, korespondencja prywatna z poszczególnymi siostrami - odpowiedzi na prośby, słowa wsparcia itp.;

- Dyrektorium Zgromadzenia Sióstr Misjonarek Świętej Rodziny (1944), czyli wskazania ascetyczne oparte na dostępnej literaturze, adresowane do sióstr Zgromadzenia i dotyczące wymagań życia zakonnego;

- Rozmyślania i czytania duchowne (1944) - uzupełniający Dyrektorium zbiór tekstów przeznaczonych do medytacji i czytania duchownego w domach zakonnych,

- modlitwy, ułożone przez Błogosławioną dla użytku własnego oraz sióstr, jak Akt dziękczynienia i poświęcenia sięśw. Rodzinie napisany z okazji srebrnego jubileuszu Zgromadzenia w 1931 roku, a także Akt ofiarowania się, będący kompilacją różnych tekstów;

- przemówienie w dniu jubileuszu 25 rocznicy powstania Zgromadzenia, wygłoszone w Ratowie 22 stycznia 1931 roku;

- myśli Bolesławy Lament zawarte we wspomnieniach spisywanych przez siostry, kapłanów oraz wychowanki zakładów prowadzonych przez Zgromadzenie, jak również odpowiedzi na kwestionariusz dotyczący Błogosławionej, z zanotowanymi w nim jej osobistymi wypowiedziami;

- obrazy sceniczne (żywe obrazy), pisane w różnych okresach, przeznaczone do wystawiania w zakładach wychowawczych i szkołach z okazji uroczystości, jak np. Mądre i głupie panny, Święta Łucja, Stary i Nowy Rok ${ }^{6}$.

Zebrana przez Adrianę Teresę Gronkiewicz obszerna bibliografia prac związanych z osobą i dziełem Bolesławy Lament odnotowuje także:

- testament (napisany w Chełmnie 5 listopada 1922 roku),

2 J. R. Bar OFMConv, Zgromadzenie Sióstr Misjonarek Świętej Rodziny, Rzym 1975, s. 97-98, 102, 104-105. Tenże autor sporządził wybór pism bł. Bolesławy (zob. przyp. 5), opublikowany w Rzymie (1975) i Warszawie (1976).

A.T. Gronkiewicz MSF, Życie i działalność Bolesławy Marii Lament 1862-1946, Założycielki Zgromadzenia Sióstr Misjonarek św. Rodziny, Warszawa 1990, s. 111-113, 284-287 i nast.

J. Stabińska OSBap, Szukać..., dz. cyt., s. 88-89, 98-144.

5 Wybór pism Bolestawy Lament (mps). Przygotował do druku o. J. R. Bar, Warszawa 1975, s. 62 .

Tamże, s. 62-66. 
- Krótki zarys Zgromadzenia SS. Misjonarek św. Rodziny (prawdopodobnie z roku 1934) ${ }^{7}$.

Ważne miejsce w rozpatrywanych zasobach tekstowych zajmuje Dyrektorium Zgromadzenia Sióstr Misjonarek św. Rodziny, zredagowane przez bł. Bolesławę na dwa lata przed śmiercią, w 1944 roku. Mianem „dyrektorium” określa się teksty normatywne uzupełniające zasadnicze konstytucje zakonne, jakkolwiek termin ten można odnieść także do zbioru praktycznych wskazówek postępowania, również $\mathrm{w}$ formie suplementu do przepisów danego instytutu. W przypadku dzieła bł. Bolesławy mamy do czynienia $\mathrm{z}$ drugim znaczeniem tego pojęcia.

Dyrektorium jest obszernym, kilkusetstronicowym tekstem zawierającym rozbudowany komentarz ascetyczny do Reguły i Konstytucji Zgromadzenia. Matka Założycielka pracowała nad nim w czasie swej ostatniej choroby, po ustąpieniu $\mathrm{z}$ urzędu przełożonej generalnej. Celem, jaki przyświecał autorce, było zachowanie ducha zakonnego, a także troska o dostęp do odpowiedniej literatury w poszczególnych domach Zgromadzenia: „Ażeby mieć odpowiednie wskazania na każdy artykuł naszych Konstytucji, potrzeba mieć bibliotekę w domu dobrze zaopatrzoną. Mając to na uwadze, że często domy nasze składać się będą z czterech lub sześciu sióstr, to trudno dostarczyć odpowiednich książek. Chcąc zaradzić temu, zebrałam $\mathrm{z}$ różnych dzieł ascetycznych autorów katolickich cenionych w Kościele i ułożyłam książkę, która by mogła dopomóc siostrom odpowiednio do pogłębienia życia zakonnego. (...) Znajdą one w niej na wszystkie artykuły odpowiednie rady i wskazówki, jak mają postępować w życiu zakonnym. W każdym domu naszego zgromadzenia znajdować się powinno niniejsze Dyrektorium. Siostry będą je używały do codziennego czytania, jak to Reguły nasze opiewają lub też do rozmyślania ku większej chwale Bożej i uświęcenia własnego dusz naszych"8.

Właściwy tekst zawierający konkretne zalecenia ascetyczne wypełnia tomy I i II, natomiast w części ostatniej znajdują się zupełnie odmienne pod względem stylu i języka rozmyślania i teksty do tzw. czytania duchownego ${ }^{9}$, charakteryzujące się szczególną dynamiką przekazu narracyjnego. Zbiór ten pierwotnie nosił tytuł Rozmyślania i czytania duchowne.

Wszystkie części Dyrektorium stanowią - w myśl zapowiedzi sformułowanej we wstępie - kompilację wybranych fragmentów tekstów ascetycznych, jak np. O postępowaniu w doskonatości i cnotach chrześcijańskich Alfonsa Rodrigueza TJ, Ćwiczenia duchowne w szkole św. Teresy od Jezusa czy Manrez czyli Ćwiczenia duchowne św. Ignacego innego jezuity, o. Roothana. Wykaz wykorzystanych

\footnotetext{
A. T. Gronkiewicz MSF, Życie..., dz. cyt., s. 328. Cennych materiałów oraz wskazówek dotyczących datacji niektórych tekstów udzieliła mi s. Joanna Mieczysława Babińska MSF, której serdecznie dziękuję. Dziękuję również s. Dorocie Duszyk MSF za udostępnienie tekstów aktualnych Konstytucji i Dyrektorium oraz modlitewnika Zgromadzenia.

8 B. M. Lament, Dyrektorium Zgromadzenia Sióstr Misjonarek Świętej Rodziny (mps), t. I, Białystok 1944, s. 4. Zob. też A.T. Gronkiewicz MSF, Życie..., dz. cyt., s. 284-285.

Wybór pism..., dz. cyt., s. 64.
} 
źródeł (łącznie osiemnaście pozycji) został zamieszczony po przedmowie autorki ${ }^{10}$. W rzeczywistości jednak podstawa materiałowa książki składa się - jak ustaliła Gronkiewicz - z około siedemdziesięciu publikacji, w tym także wydawanych za życia bł. Bolesławy, co świadczy o jej stałym zainteresowaniu nowościami z zakresu literatury dotyczącej życia wewnętrznego ${ }^{11}$.

Dyrektorium, jako chronologicznie ostatnie i najobszerniejsze z dzieł Matki Założycielki o charakterze ascetycznym można uznać za rodzaj duchowego testamentu, a także swoistą summę doświadczeń i przemyśleń autorki na temat środków prowadzących do osiągnięcia doskonałości zakonnej. Stanowiły one przedmiot szczególnej troski Błogosławionej - w odniesieniu do samej siebie, a także współsióstr i wychowanek - i były jednym z dominujących motywów jej wypowiedzi. W myśli Bolesławy Lament stały rozwój życia wewnętrznego prowadzi do świętości. „Świętość - pisze - jest niczym innym, jak życiem wewnętrznym, doprowadzonym do jak najściślejszego połączenia woli człowieka z wolą Bożą"12. Pragnieniem założycielki było osiągnięcie szczytów doskonałości - dla siebie i swych duchowych córek ${ }^{13}$. W listach adresowanych do sióstr niejednokrotnie wyraża je za pomocą zbliżonych pod względem semantycznym sformułowań, operujących metaforą „wyżyny”, „szczytu”: „Niech Bóg kochaną matkę Leokadię wspiera i prowadzi swą łaską na wyżyny świętości” ${ }^{14}$, „Niech Bóg kochaną siostrę błogosławi i dopomaga, by się wspinała nieustannie na szczyty świętości”15. Skutecznym środkiem osiągnięcia celu jest modlitwa oraz praca nad sobą: „Czuwajmy, módlmy się a pracujmy nad uświęceniem własnym pilnie i gorliwie, $\mathrm{z}$ całkowitym wyrzeczeniem się siebie, a Bóg nie odmówi swej łaski i niezadługo wszystkie się znajdziemy w orszaku wszystkich Świętych, otaczających Jezusa, Maryję i Józefa świętego. Co niech da Bóg (...)"16.

W procesie dążenia do doskonałości chrześcijańskiej istotną rolę odgrywała łączność ze świętymi. Stanowili oni - zdaniem autorki Dyrektorium - przykład doskonałego zespolenia działania łaski Bożej z wysiłkami człowieka zmierzającymi do osiągnięcia ostatecznego celu, jakim jest życie wieczne. W swych rozważaniach Bolesława Lament często podkreślała „ludzki” aspekt świętości, zdobywanej przez jednostki „Z tej ziemi”, posiadające właściwe swej naturze słabości, wady, usuwane w toku intensywnej pracy nad sobą. Czciła w sposób szczególny niektórych świętych, wskazując ich jako godne naśladowania wzorce; jedną z praktyk pobożności zalecanych siostrom było m.in. rozważanie cnót świętego patrona danego dnia oraz

10 B. M. Lament, Dyrektorium..., dz. cyt., t. I, s. 4-5.

11 A. T. Gronkiewicz MSF, Życie..., dz. cyt., s. 285.

12 B. M. Lament, Bym Cię kochała coraz więcej. Myśli wybrane. Przygotowała do druku J. M. Babińska MSF, Warszawa 1997, s. 92.

13 J. Stabińska OSBap, Szukać..., dz. cyt., s. 105.

14 Tamże, s. 105.

15 Tamże, s. 105.

16 B. M. Lament, Bym Cię kochała..., dz. cyt., s. 95. 
rozwijanie nabożeństwa do świętych ${ }^{17}$. Wpływ na ukształtowanie takiej dyspozycji wewnętrznej mogły mieć doświadczenia czasów młodości - religijna atmosfera domu rodzinnego, a szczególnie okres pozostawania pod kierownictwem duchowym ks. Antoniego Chmielowskiego - duszpasterza kolegiaty łowickiej, znanego kaznodziei, a zwłaszcza popularyzatora hagiografii, czemu dawał wyraz w swych licznych publikacjach ${ }^{18}$. Poza Świętą Rodziną, której cześć stawiała na pierwszym miejscu, do ulubionych orędowników Błogosławionej zaliczali się Apostołowie Jan i Paweł, św. Ignacy Loyola - założyciel jezuitów, którego duchowość stała się programem sióstr misjonarek ${ }^{19}$, św. Maria Magdalena - szczególnie czczona na Wschodzie i ze względu na ekumeniczny charyzmat Zgromadzenia uczyniona jedną z jego patronek, mistrzyni życia kontemplacyjnego - św. Teresa z Avili i św. Małgorzata Maria Alacoque - inicjatorka nabożeństwa do Najświętszego Serca Jezusa, męczennicy i patronowie unii kościołów wschodnich z Rzymem - święci Andrzej Bobola i Jozafat Kuncewicz. Na temat kultu świętych w Zgromadzeniu wypowiada się bł. Bolesława następująco: „Dla uproszenia sobie łask potrzebnych do spełniania tak trudnych zadań, Zgromadzenie oddaje się pod szczególną opiekę Świętej Rodziny, której uroczystość będzie pierwszorzędnym świętem Zgromadzenia. Prócz tego Zgromadzenie obchodzić będzie w szczególniejszy sposób uroczystość Najświętszego Serca Jezusowego, Najświętszej Maryi Panny Niepokalanie Poczętej, Niepokalane Serce Maryi, św. Józefa oraz św. Józefata i bł. Andrzeja Boboli, męczenników i patronów unii Kościołów wschodnich z Kościołem rzymskim. Nadto Zgromadzenie wybiera sobie na patronów: Matkę Boską Bolesną, świętych Piotra i Pawła, św. Jana Ewangelistę, św. Ignacego Loyolę, św. Franciszka Ksawerego, św. Stanisława Kostkę, św. Antoniego Padewskiego, św. Teresę, św. Marię Magdalenę i św. Teresę od Dzieciątka Jezus, św. Małgorzatę Marię"20.

17 B. M. Lament, Dyrektorium..., dz. cyt., t. I, s. 42.

18 Według relacji rodzonej siostry bł. Bolesławy, Marii Lament, wynika, że po uzyskaniu dyplomu krawieckiego w Warszawie Bolesława wróciła do rodzinnego Łowicza, gdzie „rozpoczęła życie wewnętrzne (...) pod kierownictwem ks. Antoniego Chmielowskiego”. Spośród publikacji ks. Chmielowskiego (łącznie 51 pozycji ) najliczniejszą grupę stanowią żywoty świętych oraz homilie i przemówienia okolicznościowe. Zob. A. T. Gronkiewicz MSF, Życie..., dz. cyt., s. 21.

19 J. Stabińska OSBap, Szukać..., dz. cyt., s. 144.

20 B. M. Lament, Dyrektorium, dz. cyt., s. 44. W znajdującym się w Archiwum Domu Generalnego maszynopisie modlitewnika Zgromadzenia, tzw. Pacierzówki (mps z 6. 08. 1966, s. 21, sygn. A-5a (II-8)) znajduje się modlitwa wynagradzająca o charakterzelitanii, w której wymienieni są następujący patronowie: Najświętsza Maryja Panna Niepokalanie Poczęta, święci: Michał Archanioł, Józef, Piotr i Paweł, Jan Ewangelista, Ignacy Loyola, Franciszek Ksawery, Andrzej Bobola, Jozafat Kuncewicz, Stanisław Kostka, Antoni Padewski, Maria Magdalena, Małgorzata Maria, Teresa od Dzieciątka Jezus. Również w obecnie używanym modlitewniku sióstr z 1988 r. znajdują się wezwania do patronów Zgromadzenia. W aktualnie obowiązującym Dyrektorium (rozdział 1, p. 6) czytamy: „(...) zgromadzenie od początku swego istnienia szczególną czcią otacza następujących świętych: a) Najświętszą Maryję Pannę Niepokalanie Poczętą, b) św. Józefa, c) św. Michała Archanioła, d) św. św. Apostołów Piotra i Pawła, e) św. Jana Ewangelistę, f) św. Ignacego Loyolę 
Spośród wszystkich zachowanych dzieł bł. Bolesławy Dyrektorium stanowi najobszerniejsze źródło wiedzy na temat świętych oraz ich znaczenia jako orędowników i wzorów postępowania. Poza postaciami szczególnie czczonymi w Zgromadzeniu, lista sylwetek wymienionych w analizowanym dziele obejmuje bohaterów Starego i Nowego Testamentu (Apostołowie, prorocy) poprzez starożytnych i średniowiecznych Ojców i Doktorów Kościoła (m.in. Augustyn, Beda, Katarzyna ze Sieny, Jan Chryzostom, Tomasz z Akwinu), zakonodawców (Dominik, Franciszek z Asyżu), znanych przedstawicieli zgromadzeń zakonnych (Jan Berchmans), kapłanów (Jan Maria Vianney), osoby świeckie (Cecylia, Ludwina) i inne. Przywołując i przybliżając czytelniczkom kolejne postacie autorka Dyrektorium dokonuje interesującego zabiegu w znacznym stopniu urozmaicającego wywód, przywołując różnorodne formy wypowiedzi literackiej - relacje ewangeliczne, cytaty z Dziejów Apostolskich i listów (zwłaszcza św. Pawła), fragmenty pism mistycznych, epistolografii lub tekstów normatywnych (np. wyjątki z dzieł świętych: Teresy z Avili, Małgorzaty Marii czy Ignacego Loyoli), napomnienia, egzorty (np. św. Doroteusza z Gazy, św. Franciszka z Asyżu), modlitwy świętych, pojedyncze zdania przytaczane $\mathrm{w}$ formie cytatu lub $\mathrm{w}$ mowie zależnej, a także licznie reprezentowane egzempla - przedmiot rozważań niniejszego artykułu.

Pojęcie „egzemplum” (łac. „exemplum” - „przykład”) najogólniej oznacza „krótkie opowiadanie, stanowiące pozytywną lub negatywną ilustrację wywodów umoralniających" ${ }^{21}$. Według innej definicji, gatunek ten należy do małych form literackich (opowiadanie, opis), przy pomocy których objaśniano głoszoną naukę pod kątem jej znaczenia religijnego i moralistycznego ${ }^{22}$. W dawnej literaturze polskiej termin łaciński pojawiał się wymiennie z rodzimym odpowiednikiem „przykład” oraz „historia” lub niekiedy „powieść” ${ }^{23}$. W słowniku Jana Mączyńskiego (Lexicon latino-polonicum,1564) pojęcie to wyjaśnione jest następująco: „przykład, kształt, konterfekt, przepis przykładny”. Funkcji egzemplum upatrywano

- autora ćwiczeń duchownych, g) św. Jozafata i św. Andrzeja Bobolę - męczenników i patronów Unii Kościoła wschodniego z Kościołem Rzymskim, h) św. Franciszka Ksawerego - patrona misji, i) św. Teresę od Dzieciątka Jezus - patronkę misji, j) św. Stanisława Kostkę - patrona młodzieży, k) św. Antoniego - patrona pracy charytatywnej, l) św. Teresę z Avila - wzór zjednoczenia kontemplatywnego, ł) św. Marię Magdalenę - szczególnie czczoną na Wschodzie, m) św. Małgorzatę Marię - apostołkę kultu Serca Jezusowego”. Kolejny punkt (7) postanawia: „W związku z dniem liturgicznym wyżej wymienionych świętych należy odczytać odpowiednią lekturę w celu głębszego poznania ich życia i naśladowania ich cnót”. Zob. Dyrektorium Zgromadzenia Sióstr Misjonarek Świętej Rodziny, Komorów 1985, s. 8-9 oraz Modlitewnik Zgromadzenia Sióstr Misjonarek Świętej Rodziny, Komorów 1988, s. 21-22. W 1991 r., po beatyfikacji, dodano osobę założycielki - bł. Bolesławy Lament.

${ }_{21}$ M. Głowiński, T. Kostkiewiczowa, J. Sławiński, Słownik terminów literackich, J. Sławiński (red.), Wrocław 1989, s. 134. Zob. też M. Adamczyk, Egzemplum, [w:] Słownik literatury staropolskiej (średniowiecze, renesans, barok), T. Michałowska (red.) przy udziale B. Otwinowskiej, E. Sarnowskiej-Temeriusz, Wrocław 1990, s. 154-156.

22 T. Szostek, Exemplum w polskim średniowieczu, Warszawa 1997, s. 11.

23 M. Adamczyk, Egzemplum..., dz. cyt., s. 154. 
głównie w pouczeniu odbiorcy oraz wzbudzeniu w nim zainteresowania i chęci naśladowania dobrych uczynków bohatera (bądź odrzucenia postaw jednoznacznie negatywnych). Cele te sprecyzowane zostały m.in. w przedmowie do wielokrotnie przedrukowywanego zbioru Wielkie zwierciadło przykładów Jana Majora w tłumaczeniu Szymona Wysockiego (wyd. pierwsze 1612): „[aby] mogły się dusze wiernych nie tylko z rzeczy rozmaitych ucieszyć i najwyższego sprawcy w świętych swoich postępkom się nadziwić, ale też szlachetnymi i chwały godnymi sprawami do wszelkiej pobożności pobudzić"24. Wykazując celowość oddziaływania na czytelnika poprzez tę formę wypowiedzi, odwoływano się do nauczania Chrystusa, który przedkładał konkretne przykłady postępowania w danych sytuacjach nad pouczenia werbalne (według zasady: verba docent, exempla trahunt): „Chrystus, Rządźca świata wszystkiego, naprzód począł swym przykładem czynić, potym uczyć [...]. Abowiem powiedzieć uczniom swym raczył: Przykład dałem wam, jakom ja czynił, tak i wy czyńcie”25. O skuteczności przykładu przekonywały także wypowiedzi różnych autorytetów Kościoła oraz opinie starożytnych. Jako gatunek literacki egzemplum traktowano instrumentalnie, z podkreśleniem jego znaczenia w procesie nauczania i wychowania. Postulowano także wzmocnienie jego roli perswazyjnej poprzez uwierzytelnianie autentyzmu opisywanych zdarzeń, stąd np. wskazywanie na konkretne źródła cytowanych historii. Należały do nich m.in. Pismo Święte, hagiografia, mitologia i historia starożytna, nowelistyka świecka, opowieści ludowe, anegdoty itp ${ }^{26}$.

Egzemplum rozpowszechniło się w polskiej literaturze chrześcijańskiej zwłaszcza w średniowieczu (w. XII-XIV), do czego przyczynił się rozwój kaznodziejstwa. Było popularne także w wiekach późniejszych. Będąc środkiem pouczania i przekonywania, przykład stanowił integralną część kazania (np. wywód na temat cnoty ubóstwa ilustrowano epizodami z życia św. Franciszka z Asyżu). Do dziś zachowały się zbiory kaznodziejskie wypełnione materiałem fabularnym, jak kazania Peregryna z Opola (Sermones de tempore et de sanctis z pocz. XIV w.), Fabiana Birkowskiego (Kazania na niedziele i święta doroczne, 1620) czy Franciszka Kowalickiego (Post stary polski, 1721). Powstawały też kolekcje samych egzemplów, jak wyżej wspomniane Wielkie zwierciadło przykładów. Przywoływane w opowiadaniach sylwetki i ich postępowanie wartościowano zgodnie z chrześcijańskim podziałem wyznaczonym przez kategorie dobra i zła, grzechu i cnoty ${ }^{27}$. Nieskomplikowana konstrukcja planu przedstawionego (nagroda za cnotę, kara za naganne postępowanie), w zbiorach egzemplów zwykle sygnalizowana już w formule tytułowej (np. Kara za cudzołóstwo), w sposób czytelny ujawniała moralizatorskie przesłanie i jako taka była łatwo przyswajana przez odbiorców. Budujące opowieści rozpowszechniano w formie pisemnej

\footnotetext{
24 Tamże, s. 154.

25 Tamże, s. 154.

26 Tamże, s. 154.

27 Tamże, s. 155.
} 
i ustnej, co z kolei ułatwiało proces przenikania ich do folkloru, literatury i tym samym rodzimej tradycji ${ }^{28}$.

Właściwością problemów natury moralnej jest ich uniwersalizm i ponadczasowość, co przesądziło o aktualności wspomnianej formy narracyjnej, do dziś stosowanej w homiletyce oraz tekstach nacechowanych dydaktycznie. Do tej drugiej kategorii zalicza się Dyrektorium Bolesławy Lament. Autorka, niewątpliwie świadoma skuteczności tego rodzaju przekazu, zamieściła w swym dziele sporą liczbę egzemplów w funkcji przykładów ilustrujących określone cnoty zakonne.

Rozpatrywane całostki mają zwykle formę krótkich (czasem ograniczonych do jednego czy dwóch zdań) opowiadań z życia świętych, a także związanych $\mathrm{z}$ Kościołem bohaterów niekanonizowanych, niekiedy anonimowych. Zasadniczą opowieść $\mathrm{z}$ reguły poprzedza teza, wyrażona np. w formule tytułowej rozdziału lub zdaniu sygnalizującym określone zagadnienie. W przypadku dłuższych egzemplów część narracyjną dopełnia - choć nie zawsze, jeśli wykład jest dostatecznie przejrzysty - komentarz o charakterze interpretacyjnym lub praktyczna wskazówka adresowana do odbiorcy. Charakterystycznym zabiegiem stosowanym przez autorkę jest częściowa rezygnacja $\mathrm{z}$ tzw. aparatu naukowego - informacja na temat źródeł poszczególnych historii podawana jest sporadycznie w przypisach, np. odwołanie do polskiego tłumaczenia żywota św. Jana Berchmansa pióra H. Delehaye'a ${ }^{29}$. Zgodnie z poetyką gatunku, brakuje też chronologii, a także (poza nielicznymi wyjątkami) określeń dotyczących lokalizacji przywoływanych zdarzeń; w rezultacie uwaga odbiorcy skupia się na samym bohaterze wpisanym w konkretne sytuacje życia (np. wspólnotowego), realizującym daną cnotę, a także na wypływającej z jego postępowania nauce moralnej.

Naturalnym obszarem występowania egzemplów są określone, występujące w kolejnych rozdziałach i podrozdziałach Dyrektorium zalecenia dotyczące np. sposobu odbywania formacji, życia według rad ewangelicznych, praktyk religijnych, form apostolatu i innych aspektów życia zakonnego.

I tak np. w ramach obszernego wywodu na temat celów formacji w nowicjacie i środków do ich osiągnięcia (początek ćwiczenia się w cnotach jak pokora, posłuszeństwo, umartwienie, zaparcie się siebie) bł. Bolesława zaleca wybór patrona, mającego być wzorcem do naśladowania, a zarazem orędownikiem kandydatki do życia zakonnego. Tezę-imperatyw sformułowaną w słowach: „By odbyć nowicjat, nowicjusz obierze sobie Patrona jako wzór i opiekuna” popiera przykładem z życia św. Jana Berchmansa ${ }^{30}$. W poniższym egzemplum przedmiotem uwagi

28 Tamże, s. 156.

29 B. M. Lament, Dyrektorium, dz. cyt., t. I, s. 12.

30 Tamże, s. 12. Św. Jan Berchmans (ur. 1599), belgijski jezuita, wstąpił do Towarzystwa Jezusowego w wieku 17 lat. Cechowało go głębokie życie modlitwy, zwłaszcza nabożeństwo do Męki Pańskiej, wierność obowiązkom zakonnym oraz miłość braterska. Po studiach filozoficznych w Rzymie zachorował. Zmarł w 1621, jest patronem ministrantów i studentów. Zob. H. Fros SJ, F. Sowa, Księga imion i świętych, t. 3, Kraków 1998, s. 255. 
stają się przymioty bohatera (wierność w zachowywaniu przepisów zakonnych, wynikająca z pokory świadomość własnych niedoskonałości), ujawniające się w relacjach z przełożonymi i współbraćmi, składające się na zespół modelowych postaw zalecanych na wspomnianym etapie formacji: „Ten anielski młodzieniec odznaczył się zamiłowaniem i pilnością w zachowaniu reguł i przepisów, co powinno być główną cnotą nowicjusza. Od wstąpienia do nowicjatu dawał dowody wysokiej doskonałości. Najbardziej wyćwiczone oko nie było w stanie znaleźć w nim najmniejszej winy. Pomimo to nie przestawał prosić Mistrza nowicjatu, by go publicznie karcił za przewinienia. Przełożony, nie widząc w nim nic zdrożnego, a chcąc uczynić zadość jego prośbie, kazał nowicjuszom napisać winy młodego zakonnika. Lecz - o zachwycająca doskonałości! Choć w nowicjacie było podówczas więcej niż 100 nowicjuszów, żaden z nich nie dostrzegł w nim ani jednego błędu" ${ }^{31}$.

Postać świętego jako wzorcowego wykonawcy przepisów zakonnych wspomniana jest również w podrozdziale poświęconym zachowywaniu reguł, rozumianych jako pewna droga doskonałości dla osób konsekrowanych. Prawdę tę uzasadnia autorka następująco: „Młody ten Święty nie uczynił w swym życiu żadnego cudu, nie podejmował wielkich pokut, nie miał zachwyceń na modlitwie; nie dokonał nic nadzwyczajnego; lecz w sposób doskonały zachowywał wszystkie reguły, a w krótkim czasie doszedł do wysokiej doskonałości, do prawdziwej świętości. I nic w tym dziwnego; reguły bowiem każdego zakonu, zatwierdzone przez Kościół, są przeznaczone na to, by prowadziły członków zgromadzenia drogą doskonałości, stosownie do jego ducha i celu"32.

W różnych partiach dzieła odnaleźć można inne, starannie dobrane epizody, wskazujące na erudycję autorki oraz jej znajomość przymiotów poszczególnych świętych, realizujących odpowiednie zalecenia. O potrzebie wypracowania umiejętności godzenia życia wewnętrznego z codziennymi obowiązkami przekonuje sposób życia św. Dominika, założyciela Zakonu Kaznodziejskiego. Założenie: „im więcej mamy zajęć, tym większa potrzeba modlitwy i pomocy Bożej, aby je należycie wykonać"33 obrazuje przykład bohatera umiejętnie dzielącego - na wzór Chrystusa - czas pomiędzy życie duchowe a aktywność apostolską. Cytowane egzemplum wskazuje na zasługującą wartość zjednoczenia z Bogiem na modlitwie jako aktu przygotowawczego do pracy wśród ludzi i gwarantującego powodzenie pełnionej misji: „O Świętym Dominiku czytamy, że czas swój na dwie części podzielił: w dzień obcował z ludźmi, a w nocy z Bogiem, dlatego też wielki owoc przynosiła jego nauka, bo w nocy naradzał się z Bogiem nad tym, co miał we dnie czynić i pierwej polecał Bogu to, co chciał uczynić, nim z ludźmi zaczął obcować. I Chrystus, Pan nasz, dał nam tego przykład (...). W dzień chodził z miejsca na

\footnotetext{
$31 \quad$ B. M. Lament, Dyrektorium..., dz. cyt., t. I, s. 12.

32 Tamże, t. II, s. 162.

33 Tamże, t. I, s. 30.
} 
miejsce, opowiadając i nauczając, lecząc chorych i opętanych, w nocy zaś czuwał i trwał na modlitwie" 34 .

Przywołane w dziele bł. Bolesławy zdarzenia z życia Doktorów Kościoła św. Alberta Wielkiego, św. Tomasza z Akwinu oraz św. Bonawentury - stanowią kontynuację podjętego motywu i wskazują na znaczenie prymatu modlitwy nad studiami, starań o postęp wewnętrzny nad rozwój intelektualny. W wymownej historii franciszkańskiego Doktora Kościoła krucyfiks na klęczniku bohatera otrzymuje wykładnię symboliczną - światła oświecającego ludzki umysł bardziej niż lektura uczonych dzieł. Ukazując wizerunek Ukrzyżowanego św. Tomaszowi, Bonawentura stwierdza: „Oto moje książki (...), to moja najważniejsza księga, z której czerpię wszystkie wykłady i pisma moje" ${ }^{35}$. Wierność modlitwie jest również tematem egzemplum o św. Bernardzie z Clairvaux, w którym „dynamiczne" ujęcie przemieszczającego się często zakonnika kontrastuje ze stałością jego postawy wewnętrznej: „Zmieniał miejsca pobytu, lecz nie zmienił serca, ani serce nie zmieniło miłości, ani miłość przedmiotu (...), był zawsze złączony z Bogiem (...."36. Innego przykładu mającego uświadomić czytelniczkom potrzebę stałego kontaktu z Bogiem dostarcza św. Cecylia, nierozstająca się ani na chwilę z noszoną na sercu Ewangelią ${ }^{37}$. Wierność określonym formom modlitwy, np. różańcowej, zalecanej siostrom odrębnymi przepisami, ilustrują postawy Piusa V, Karola Boromeusza, Jana Berchmansa, Franciszka Ksawerego, Alfonsa Liguoriego i Franciszka Salezego ${ }^{38}$.

Z powyższym zagadnieniem łączy się szczegółowo potraktowana w dziele Błogosławionej kwestia uczestnictwa i zachowania podczas nabożeństw, zwłaszcza Mszy św., przynoszącej obfite owoce duchowe. Modelową postawę w tym zakresie prezentuje jezuicki święty Alfons Rodriguez; ogarnięty pragnieniem codziennej Eucharystii, uczestniczy w niej bez względu na okoliczności zewnętrzne. W poświęconym mu opowiadaniu bohater występuje w roli ministranta, zaś na temat jego budującego zachowania czytelnik dowiaduje się pośrednio na podstawie reakcji świadków zdarzeń: „Wiele osób chciało wiedzieć, kiedy on miał służyć do Mszy świętej, by słuchać tej właśnie Mszy. Widząc, iż Alfons zabiera się służyć do drugiej Mszy, pozostawali w kościele, by być świadkami jego pobożności. Kapłani, którym służył (...), czuli się przejęci gorliwością; a gdy który z nich chciał polecić Panu Bogu sprawę wielkiej wagi, starał się, by mu Alfons do Mszy służył39. Wykładnię interpretacyjną egzemplum stanowi - przytoczone w funkcji wypowiedzi uznanego autorytetu - pouczenie autorstwa św. Piotra Klawera, misjonarza

\footnotetext{
Tamże, s. 30.

Tamże, s. 31.

Tamże, s. 119.

Tamże, s. 186.

Tamże, t. II, s. 3.

Tamże, t. I, s. 182.
} 
Afryki, zalecające m.in. częsty udział w Eucharystii ${ }^{40}$. Pragnienie częstego pełnego uczestnictwa we Mszy św. (zalecanego każdej siostrze Zgromadzenia) uosabiają św. Małgorzata Maria Alacoque i dominikańska tercjarka św. Róża z Limy, z utęsknieniem wyczekujące Komunii św. ${ }^{41}$, zaś młodociani bohaterowie jezuiccy, jak św. Alojzy Gonzaga i św. Stanisław Kostka stanowią wzorce pokory i ufności w momencie przyjmowania Ciała Chrystusa ${ }^{42}$.

Pojedyncze jednostki tekstowe poświęcone są kwestii realizacji rad ewangelicznych. Zdaniem autorki, ich zachowywanie stanowi główny środek zdobywania doskonałości i należy przeżywać je jako najcenniejszą ofiarę składaną Bogu przez zakonnika. W wymownej historii zaczerpniętej z kronik zakonu Braci Mniejszych św. Franciszek z Asyżu, pragnący - na rozkaz Chrystusa - złożyć Mu trojaki dar, ofiarowuje trzy przypadkowo znalezione w zanadrzu monety. Autor egzemplum nadaje im symboliczne znaczenie trzech ślubów zakonnych: „[Pan] mu wytłumaczył, że te trzy monety oznaczają: złote posłuszeństwo, drogocenne ubóstwo i piękną czystość. Te zaś trzy ofiary z łaski Bożej tak doskonale Panu złożyłem, że wich zachowaniu sumienie mi nic nie wyrzuca" ${ }^{43}$. Sam sens opowiadania zastępuje tu jednoznaczny morał, stąd miejsce komentarza interpretacyjnego zajmuje krótka zachęta skierowana do odbiorcy: „więc i my ofiarujmy Bogu te trzy śluby tak, aby nam w ich zachowaniu sumienie żadnego nie czyniło wyrzutu" ${ }^{44}$.

Kolejne partie Dyrektorium, poświęcone rozpatrywanemu zagadnieniu, urozmaicane są dalszymi budującymi przykładami, umieszczonymi w bliskich czytelniczkom zdarzeniach, głównie z życia monastycznego. Przedstawiają one wizerunek społeczności hierarchicznych, w których przełożeni udzielają podwładnym - za pośrednictwem słów lub gestów - wskazań dotyczących cnotliwego życia. Ilustracją tezy postulującej posiadanie jedynie rzeczy niezbędnych do życia jest opowieść zestawiająca dwie odmienne postawy wobec ślubu ubóstwa: towarzysza św. Franciszka z Asyżu, brata Eliasza, sprawiającego sobie wygodny habit z szerokimi rękawami i z kosztownej tkaniny oraz, na zasadzie antytezy, Biedaczyny zadowalającego się znoszoną, ubogą szatą. We wspomnianym egzemplum zastosowano również interesujące porównanie zachowań bohatera, modyfikowanych w zależności od rodzaju noszonego stroju - pewność siebie i pychę, wyrażaną za pomocą gestów, spojrzeń i sposobu odnoszenia się do obecnych (Franciszek w habicie Eliasza) oraz pokorę, radość i uprzejmość będące rezultatem osiągnięcia

40 Tamże, s. 182.

41 Tamże, t. III, s. 139. Św. Róża z Limy (1586-1617) w dwudziestym roku życia została tercjarką dominikańską. Odznaczała się życiem kontemplacyjnym, pełnym wyrzeczeń, poświęcała się posłudze wśród chorych i biednych. Doznawała łask mistycznych. Jest patronką Ameryki Południowej. Zob. W. Piszczek CM, Wspomnienie świętych na każdy dzień. Martyrologium, Kraków 2005, s. 206.

42 B. M. Lament, Dyrektorium..., dz. cyt, t. I, s. 140.

43 Tamże, s. 33.

44 Tamże, s. 33. 
stanu wolności wewnętrznej (Franciszek w swej codziennej, zniszczonej tunice) ${ }^{45}$. Przeciwstawione sobie w ramach tej samej jednostki tekstowej typy, dzięki swej opozycyjności, wyraźnie akcentują skutki wyborów dokonywanych przez ludzi oraz wskazują właściwą drogę postępowania. Mocy argumentu dowodowego nabiera zamieszczony w sąsiedztwie opowiadania cytat z pism św. Bonawentury, zachęcającego do posiadania przedmiotów nie tylko najbardziej potrzebnych, lecz także przedstawiających znikomą wartość ${ }^{46}$.

Konsekwentnym dopełnieniem rozważań na temat ślubu ubóstwa jest historia św. Doroteusza z Gazy ${ }^{47}$, wychowującego swego ucznia św. Dozyteusza ${ }^{48} \mathrm{w}$ duchu nieprzywiązywania się do rzeczy materialnych ${ }^{49}$. Kwestię poszanowania przedmiotów będących własnością domu zakonnego poruszają zaczerpnięte z pism Kasjana inne przykłady zachowań świątobliwych członków pierwotnych wspólnot monastycznych; szczególną wymowę posiada historia mnicha poddającego się publicznej pokucie z powodu upuszczenia na ziemię trzech ziaren soczewicy przeznaczonych do ugotowania ${ }^{50}$.

Znaczenie czystości konsekrowanej ukazuje bł. Bolesława na przykładzie św. Alojzego Gonzagi i innych świętych młodzieńców (Jan Berchmans, Stanisław Kostka), podejmujących wysiłki ascetyczne w celu poskromienia nieuporządkowanych skłonności, jakkolwiek w komentarzu odautorskim zaleca roztropność w stosowaniu umartwień cielesnych ${ }^{51}$. Wszyscy trzej jezuiccy bohaterowie ujmują otoczenie skromnym, budującym wyglądem, będącym odbiciem ładu wewnętrznego ${ }^{52}$. Wielokrotnie wspominany w Dyrektorium św. Alojzy posiada wszystkie

45 „Opowiadają kroniki (...), że brat Eliasz (...) kazał dla siebie zrobić habit obszerny z szerokimi rękawami i z drogiego sukna. (...) Wdział go tedy św. Franciszek na swój habit, ułożył pięknie fałdy, poprawił kaptur, zagiął poważnie rękawy, zrobił minę uczonego i zaczął chodzić dumnie z zadartą głową (...). Bracia się zdumieli, gdy zobaczyli, co mówi i czyni św. ich Ojciec. Gdy to uczynił św. Franciszek, z gniewem zdarł z siebie ten habit i rzucił go precz z pogardą, mówiąc do brata Eliasza (...): „Tak chodzą nieprawi synowie zakonu”. Zostawszy zaś w swym habicie ubogim (...), rozjaśnił oblicze wesołością (...) i z wielką pokorą, uprzejmością zaczął rozmawiać z braćmi”. Zob. B. M. Lament, Dyrektorium..., dz. cyt., t. I, s. 66.

46 Tamże, s. 66.

47 Św. Doroteusz z Gazy pochodził z Antiochii. Tam otrzymał staranne wykształcenie. Około 525 roku schronił się w klasztorze niedaleko Gazy (Palestyna), zaś 15 lat później założył klasztor, gdzie pełnił urząd przełożonego (ihumena). Zachowały się jego pouczenia dotyczące życia duchowego. Zob. H. Fros SJ, F. Sowa, Księga imion..., dz. cyt., t. 2, Kraków 1997, s. 73.

48 Św. Dozyteusz pochodziłz Palestyny. Po otrzymaniu wizji przedstawiającej piekło, wstąpił do klasztoru założonego przez św. Doroteusza i poddał się jego kierownictwu. Wspominany jest w pouczeniach św. Doroteusza. Zob. tamże, s. 74.

49 „Tak czynił św. Doroteusz z uczniem swym Dozyteuszem. Kazał mu np. zrobić suknię i uszyć tak, aby mu dobrze leżała; gdy ją więc Dozyteusz bardzo pięknie i gładko uszył dla siebie, brał mu ją i dawał drugiemu". Zob. B. M. Lament, Dyrektorium..., dz. cyt., t. I, s. 67.

50 Tamże, s. 95 i 109.

51 Tamże, s. 88.

52 Tamże, t. III, s. 60. 
walory idealnego członka rodziny zakonnej; jedną z eksponowanych cech bohatera jest pokorne przyjmowanie upomnień, nawet za niepopełnione przewinienia ${ }^{53}$.

Wartość posłuszeństwa, polegającego na całkowitym poddaniu woli własnej zarządzeniom przełożonych oraz przepisom zakonnym, przedstawiona jest w opowiadaniach z udziałem Ojców i mnichów pustyni przerywających rozpoczęte prace na głos przełożonego lub dźwięk dzwonu wzywający ich do innych zajęćs $^{54}$, a także świętych czasów nowożytnych, jak np. Franciszka Ksawerego, zamierzającego niezwłocznie porzucić pracę misyjną po otrzymaniu wezwania do powrotu do kraju. W spełnieniu polecenia przełożonego przeszkodziła mu jedynie śmierćs ${ }^{5}$. Centralną postacią innej, obszernej anegdoty jest anonimowy zakonnik uchylający się od rozmowy z odwiedzającym klasztor księciem z powodu nakazu milczenia; zakończenie historii przynosi obraz dostojnika zbudowanego postawą mnicha, sam w sobie posiadający walor egzemplaryczny, niewymagający dalszego komentarza ${ }^{56}$. Korzyści z zachowania najdrobniejszych przepisów reguły w duchu posłuszeństwa (postawa wierności w małym) poparte są przykładem św. Jana Berchmansa oraz bezimiennego zakonnika, cierpliwie znoszącego obecność naprzykrzających się dzieci ${ }^{57}$.

Istotnym wskazaniem kierowanym do adresatek Dyrektorium jest pielęgnowanie ducha pokuty oraz wynagrodzenia Bogu za krzywdy wyrządzane Mu przez ludzi. Niedoścignionym wzorem przemiany wewnętrznej prowadzącej od życia grzesznego do nawrócenia pozostaje św. Maria Magdalena. Przywoływana jest $\mathrm{w}$ wielu miejscach jako ideał osoby świadomej swych błędów i dążącej do pojednania z Bogiem. W rozdziale dotyczącym skruchy serca ukazana jest w kluczowych, decydujących dla jej życia momentach: spotkania z Chrystusem w czasie uczty u Szymona (tu zwraca uwagę rozbudowany opis uniżenia bohaterki u stóp Jezusa), na Kalwarii pod Krzyżem, w poranek Zmartwychwstania ${ }^{58}$. Cytowanym fragmentom towarzyszy zachęta do naśladowania pokutnej postawy świętej i ćwiczenia się w cnocie pokory. W innych partiach tekstu Magdalena towarzysząca Ukrzyżowanemu i z tego tytułu wystawiona na pośmiewisko żołnierzy przywoływana jest jako wzór wytrwałości w znoszeniu obelg ${ }^{59}$. Kiedy indziej służy jako przykład ufności i miłości ${ }^{60}$. O dostępnej dla każdego możliwości nawrócenia, zwłaszcza poprzez wyznanie grzechów w sakramencie pokuty i pojednania,

53 Tamże, t. II, s. 115.

54 „...) skoro tylko usłyszeli głos dzwonka lub przełożonego, natychmiast wychodzili ze swoich cel i to tak prędko, iż ten, co pisał, nie dokończył nawet litery zaczętej; ponieważ wyżej cenili posłuszeństwo, niż wszystko inne (...). Zob. B. Lament, Dyrektorium..., dz. cyt., t. I, s. 109.

55 Tamże, s. 121.

56 Tamże, t. II, s. 176.

57 Tamże, s. 104-105.

58 Tamże, s. 32.

59 Tamże, s. 139-140.

60 Tamże, t. I, s. 130. 
przekonują także krótkie wzmianki na temat św. Piotra Apostoła, św. Augustyna oraz franciszkańskiej pokutnicy św. Małgorzaty z Kortony ${ }^{61}$.

Przewodnikami na drodze realizacji postawy wynagradzającej są bł. Jan z Avili $^{62}$, współczujący objawionemu mu Chrystusowi umęczonemu i niosącemu krzyż (w tekście zwraca uwagę opis cierpienia malującego się na twarzy Jezusa) oraz św. Małgorzata Maria Alacoque - patronka Zgromadzenia i apostołka kultu Najświętszego Serca Jezusa, wielokrotnie wspominana w dziele bł. Bolesławy w kontekście słynnych objawień ${ }^{63}$. Wizytka z Paray-le-Monial służy także przykładem przezwyciężania naturalnych skłonności do ludzi oraz niechęci do pewnych przedmiotów i czynności: „Pierwszym zwycięstwem było, kiedy na żądanie Mistrza wyrzekła się zbyt wyłącznej i naturalnej przyjaźni ku jednej ze swych sióstr zakonnych; drugim zaś, gdy wierna chwilowemu natchnieniu, dla miłości Bożej, mężnie zwyciężyła wstręt wrodzony w refektarzu"64.

Sugestywny przykład pokory i zaparcia się siebie towarzyszy wskazaniom dotyczącym posługi w zakonnej infirmerii. Obraz św. Ignacego Loyoli, dobrowolnie oddającego się pracom służebnym w szpitalu, odznacza się poetyką znaną z hagiografii średniowiecznej, np. żywotów św. Elżbiety Węgierskiej ${ }^{65}$. Bohater, człowiek wielkiej delikatności, pielęgnuje chorych wzbudzających największą odrazę, zaprezentowanych $\mathrm{z}$ zastosowaniem elementu naocznego przedstawienia: „Wykwintna jego natura wzdrygała się na widok brudu, ran i wrzodów; lecz właśnie dlatego, aby gwałt naturze swej zadać, wyszukiwał chorych, których dolegliwości przejmowały go największym wstrętem (...), ściskał ich jako braci kochanych i tak starannie, i tak długo ich pielęgnował, aż zdawało mu się, że ów pierwotny wstręt ustąpił"66.

Szereg przykładów ukazuje wartość podporządkowania się woli Bożej jako istotnego czynnika warunkującego postęp w życiu wewnętrznym. Egzemplifikację wspomnianej tezy odnaleźć można w zdarzeniu z życia np. Teresy z Avili, zmuszonej wskutek nagłej choroby do rezygnacji z umartwień zaplanowanych na czas rekolekcji. Zamysł Boży względem zawiedzionej w swych zamiarach bohaterki

${ }_{61}$ Tamże, s. 128. Św. Małgorzata z Kortony (1247-1297), zwana „franciszkańską Magdaleną”, w młodości wiodła nieuporządkowane życie. Tragiczna śmierć kochanka i odnalezienie jego rozkładającego się ciała przyczyniły się do jej nawrócenia. Małgorzata rozpoczęła życie pokutne i wstąpiła do III Zakonu św. Franciszka. Zob. W. Piszczek CM, Wspomnienie..., dz. cyt., s. 57-58.

62 Bł. Jan z Avili (1499-1569) hiszpański kapłan, kaznodzieja, organizator misji ludowych zwany „A postołem Andaluzji”, fundator kilkunastu kolegiów, autor pism. Zob. H. Fros SJ, F.Sowa, Księga imion..., dz. cyt., t. 3, Kraków 1998, s. 243.

63 B. M. Lament, Dyrektorium..., dz. cyt., t. I, s. 156.

64 Tamże, s. 25.

65 Św. Elżbieta Węgierska (1207-1231), córka króla Węgier Andrzeja II, landgrafini Turyngii, słynęła z dzieł miłosierdzia, m.in. pielęgnowania chorych w zakładanych przez siebie szpitalach, co niejednokrotnie podkreślają ówczesne źródła, np. świadectwo spowiednika świętej lub żywot pióra dominikanina Teodoryka z Apolda, ok. 1280 (przyp. aut.).

66 B. M. Lament, Dyrektorium..., dz. cyt., t. II, s. 155. 
zostaje zwerbalizowany za pomocą słów Chrystusa: „Przygotowałaś sobie sama włosiennicę (...). Chciałaś biczować się własną dyscypliną. Ja tymczasem sam to uczynię; przyjmij włosiennicę ode mnie: jest nią gorączka oraz pokrzyżowanie twych planów"67. Święta przyjmuje pouczenie bez protestów, co zostaje stwierdzone w zdaniu podsumowującym opowiadanie; dalszy komentarz jest zbyteczny. Podobną dyspozycję wykazuje wspomniany św. Ignacy Loyola, porzucający ze względu na Boga oraz dobro bliźnich - pragnienie samoponiżania się („wielkie pragnienie wspomagania dusz przytłumiło w nim żądzę upokorzenia się i sprawiło, że postępował z powagą i godnością odpowiednią stanowisku, jakie zajmował i opuszczał swe nadzwyczajne umartwienia") ${ }^{68}$. Duch wyrzeczenia cechuje także św. Gertrudę $e^{69}$; znalazłszy się na dnie przepaści, w sytuacji zagrażającej życiu i uniemożliwiającej przyjęcie ostatnich sakramentów, w dialogu z siostrami wyraża całkowitą gotowość przyjęcia każdego rodzaju śmierci, nawet bez pociechy religijnej ${ }^{70}$. Godnym naśladowania wzorcem zjednoczenia z Ukrzyżowanym Chrystusem jest postawa św. Ludwiny ${ }^{71}$ wobec dręczącej ją choroby. W opisie cierpień bohaterki zaakcentowano wytrwałość w znoszeniu trwającego trzydzieści sześć lat kalectwa, rodzaje doświadczeń natury fizycznej i duchowej oraz, inspirowane wizerunkiem z krucyfiksu, pragnienie dalszych umartwień z miłości do Jezusa ${ }^{72}$.

Duch apostolstwa zakonnego ukazany jest w dwóch zasadniczych formach. Postać ukryta, zasadzająca się na modlitwie i składaniu ofiar z miłości dla Chrystusa, znajduje swe najpełniejsze odzwierciedlenie w postawie św. Teresy od Dzieciątka Jezus, nawracającej świat według „nazaretańskiej metody” - zza klauzury, bez rozgłosu (podobnie czyniły św. Teresa z Avili i św. Małgorzata Maria). Święta z Lisieux poucza też - w wielu miejscach Dyrektorium - na temat wartości realizowania „małej drogi” miłości i ufności, dostępnej dla wszystkich, niewymagającej wielkich, spektakularnych działań, zasługującej w takim samym stopniu jak czynna aktywność wśród świata ${ }^{73}$. Na tym samym biegunie sytuuje się postać franciszkańskiej tercjarki Róży z Viterbo, prowadzącej żywot pustelniczy i podejmującej umartwienia w intencjach Kościoła ${ }^{74}$. Model apostolatu aktywnego reprezentują święci misjonarze, jak Franciszek Ksawery. W obu przypadkach tajemnica apo-

$67 \quad$ Tamże, s. 79.

68 Tamże, t. I, s. 27.

69 Św. Gertruda, ur. w 1256 r. w Niemczech, w wieku lat pięciu została oddana na wychowanie do cysterek w Helfcie. Pozostała w klasztorze i po osiągnięciu pełnoletności została zakonnicą. Swe doświadczenia mistyczne zawarła w traktacie Objawienia Bożej miłości. Zmarła w 1302 r. Zob. W. Piszczek CM, Wspomnienie..., dz. cyt., s. 268-269.

70 B. M. Lament, Dyrektorium..., dz. cyt., t. II, s. 158.

${ }_{71}$ Św. Ludwina, ur. w 1380 r. koło Rotterdamu, w piętnastym roku życia uległa wypadkowi i do końca życia pozostawała w łóżku. Odznaczała się heroizmem w znoszeniu cierpień, dostąpiła również łask mistycznych. Zmarła w 1433 r. Zob. W. Piszczek CM, Wspomnienie..., dz. cyt., s. 96.

72 B. M. Lament, Dyrektorium..., dz. cyt., t. II, s. 158.

73 Tamże, s. 121.

74 Tamże, t. III, s. 107. 
stolstwa polega jednakże na umiejętności kochania, żywej i głębokiej miłości Boga i bliźniego, zdolnej pochłonąć ludzkie wady. Cnotę tę, podobnie zresztą jak wszystkie inne, zdobywa się w toku intensywnej pracy nad sobą ${ }^{75}$.

Niniejsze opracowanie nie wyczerpuje całości problematyki sygnalizowanej $\mathrm{w}$ formule tytułowej, koncentrując się - z nielicznymi wyjątkami - na reprezentatywnych postaciach świętych i egzemplach obecnych w Dyrektorium bł. Bolesławy Lament. Należą do nich przede wszystkim przykłady z życia patronów czczonych w Zgromadzeniu, zwłaszcza świętych Towarzystwa Jezusowego inspirujących duchowość Misjonarek Świętej Rodziny. Nie brakuje też sylwetek z kręgu karmelitańskiego, franciszkańskiego czy przedstawicieli duchowości salezjańskiej. Poświęcone poszczególnym bohaterom jednostki tekstowe ukazują ich jako ludzi pielęgnujących cnoty chrześcijańskie, składające się na kanon cech charakteryzujących wybrańca Bożego. Nie oznacza to jednak całkowitego wyobcowania świętego ze świata i jego problemów, a tym samym zwolnienia od pracy wewnętrznej. Zaprezentowane wyżej zdarzenia ukazują obraz człowieka, któremu nieobca była właściwa jego ułomnej naturze kondycja, jakkolwiek dzięki czynionym wysiłkom - już za życia otaczała go sława przyszłej świętości.

75 Tamże, t. I, s. 105. 